\title{
Fulfillment of Labor Rights for Persons with Disabilities in Indonesia
}

\author{
Nazifah $^{1, *}$, Dewa Gede Sudika Mangku² and Ni Putu Rai Yuliartini \\ ${ }^{1}$ Faculty of Law, Universitas Batanghari, Jl. Letkol Slamet Riyadi No. 1 Broni Kel. Sungai Putri Kec. Danau \\ Sipin Jambi 36124, Indonesia \\ ${ }^{2}$ Faculty of Law and Social Sciences, Universitas Pendidikan Ganesha, Jalan Udayana No. 11 Singaraja Bali, \\ Indonesia
}

Abstract: The purpose of this research is to fulfill the rights of persons with disabilities to obtain jobs following their fields without reducing their rights. The research method used is normative juridical with literature study. Decent work is a right for every human being without exception. Various racial, ethnic, and religious backgrounds that are part of a human's identity do not become a barrier for him to get his right. Likewise with the physical or non-physical conditions that underlie a human being. Every human being who has a certain physical or non-physical background also has the same rights to get decent work, including persons with disabilities. The State of Indonesia ratified the Convention on the Rights of Persons with Disabilities into Law Number 19 of 2011. In the preamble of the law, it was explained that the countries that signed the convention had the obligation to promote and protect the rights and dignity of persons with disabilities and promote their participation in the civil, political, economic, social, and cultural spheres is based on equal opportunities, meaning that the Indonesian Government is obliged by law to fulfill the rights of persons with disabilities, especially about the right to work in Indonesia.

Keywords: People with disabilities, Indonesia, labor.

\section{INTRODUCTION}

In the amendment to the 1945 Constitution of the Republic of Indonesia the fourth amendment, Chapter XA regulates Human Rights, the addition of the Human Rights formula and guarantees of respect, protection, implementation, and advancement in the 1945 Constitution not solely because of the desire to accommodate developments a view of human rights that is increasingly considered to be important as a global issue, but because it is one of the requirements of a rule of law. With the human rights formula in the 1945 Constitution, constitutionally the human rights of every citizen and population of Indonesia have been guaranteed. In this connection, the Indonesian people have the view that human rights must pay attention to the characteristics of Indonesia and a human right must also be balanced with obligations so that it is hoped that mutual respect and respect for the human rights of each party will be created. One of the aspects of the human rights formulation included in the 1945 Constitution is human rights related to social welfare. Equal rights and obligations for all citizens in all aspects of life and livelihood are a prerequisite for achieving social welfare for all Indonesian people (Mangku, D. G. S, 2020).

The Republic of Indonesia which is based on Pancasila and the 1945 Constitution of the Republic of

*Address correspondence to this author at the Universitas Batanghari Jambi, Indonesia; Tel/Fax: +62 741 60673; E-mail: nazifahthojib@gmail.com
Indonesia respects and upholds human dignity. Human rights as basic rights that are naturally inherent in humans, are universal and lasting, are also protected, respected, and defended by the Republic of Indonesia, so that the protection and promotion of human rights, including for vulnerable groups, especially persons with disabilities, also need to be improved (Mangku, DGS, \& Yuliartini, NP R, 2019).

Human rights are basic rights that are inherently attached to the nature and existence of humans as creatures of the One and Only God and are His gifts. Human rights must be respected, protected, fulfilled, upheld, and promoted for the sake of human dignity. The implementation of respect, fulfillment, protection, upholding, and advancement of human rights is an obligation and responsibility of the state, especially the government. This is as mandated in Article 281 paragraph (4) of the 1945 Constitution of the Republic of Indonesia and Article 71 of Law Number 39 of 1999 concerning Human Rights (Zainal, et al. 2006).

In regulating persons with disabilities, the State of Indonesia already has laws and regulations relating to this matter. In 1997, Indonesia issued Law Number 4 of 1997 concerning Persons with Disabilities (Yuliartini, NPR, \& Mangku, DG S, 2020), then in 2016 Indonesia again replaced the law relating to persons with disabilities with persons with disabilities through the Law Law Number 8 of 2016. There has been a shift in meaning from a person with disabilities to a person with a disability, in Law Number 4 of 1997 concerning 
Persons with Disabilities, in Article 1 paragraph (1) referred to as having a disability is anyone who has a physical and/or mental disability, who can interfere or constitute an obstacle and obstacle for him to do his right, which consists of (a) persons with physical disabilities; (b) mentally disabled, and (c) physically and mentally disabled. In Article 1 paragraph (1) of Law Number 8 the Year 2016, it is explained that persons with disabilities are everyone who experiences physical, intellectual, mental and/or sensory limitations for a long period who interacts with the environment may experience obstacles and difficulties to participate. fully and effectively with other citizens based on equal rights (Husni, 2003).

The Republic of Indonesia which is based on Pancasila and the 1945 Constitution of the Republic of Indonesia respects and upholds human dignity. Human rights as basic rights that are inherently universal, need to be protected, respected and defended, so that respect, protection, and fulfillment of human rights for vulnerable groups, especially persons with disabilities, are state obligations (Khairani, 2012).

Life and work are two sides of a coin, so that humans can live, they must work. Humans as social creatures (zoon political) have various needs, which include clothing, shelter, food. To fulfill these various needs, humans are required to work because with their work they can earn an income. In this case, the right to work has been explicitly regulated in Article 27 of the 1945 Constitution (Rizqa Maulinda, Dahlan, M. Nur Rasyid, 2016).

Manpower is development actors and economic actors, both individually and in groups, so that they have a very significant role in national economic activities, namely increasing the productivity and welfare of the community. In Indonesia, the workforce is one of the driving forces for economic life and is a resource that is quite abundant. This indication can be seen in the high number of unemployed people in Indonesia and the low or minimal job opportunities provided.

In doing work, a person can do business on their own (entrepreneurship) or can work for other people and this is related to Labor Law. Labor law is a part of the applicable laws (all regulations) which are the basis for regulating the working relationship between a worker (worker) and his employer or company, regarding life and work procedures that are directly related to the working relationship (Zainal, et al. 2006). Meanwhile, based on the definition of manpower, labor law is all legal regulations relating to labor, both before or during an employment relationship, and after a working relationship (Lalu Husni, 2003; 24).

Article 27 paragraph (2) of the 1945 Constitution of the Republic of Indonesia affirms that every Indonesian citizen has the right to work and a decent living. This article can be interpreted that the state is responsible for the constitutional rights of citizens (Yuliartini, N. P. R., \& Mangku, D. G. S. 2020). Manpower is one of the fields as an effort to improve one's welfare, even though it is faced with limited employment opportunities. Apart from being limited, other serious problems are faced related to protection, wages, welfare, industrial relations disputes, fostering, and labor inspection. There are weaknesses in the government systemically in implementing the Manpower Law, even there tend to be irregularities. Another thing is the problem of coordination and performance between government agencies that are not optimal and cause for concern.

\section{RESEARCH AIM}

The purpose of this study is to analyze the fulfillment of labor rights for people with disabilities in Indonesia.

\section{LITERATUR REVIEW}

\subsection{Rule of Law Theory}

The term rechtsstaat which is translated as rule of law according to Philipus M. Hadjon (1996) has become popular in Europe since the 19th century, although there has been a long history of thinking about it. The idea of a rule of law was put forward for the first time by Plato and then Aristotle emphasized this thought (Huda, 2005). According to Aristotle, it is not humans who rule in a country, but a fair mind and decency that determines the good or bad of a law. According to Aristotle, a good country is a country ruled by a constitution and has the rule of law. He stated (Sabine, 1995): "Constitutional rule in a state is closely connected, also with the requestion whether is better to be ruled by the best men or the best law, since a government in accordance with the law, accordingly the supremacy of law is accepted by Aristoteles as a mark of good state and not merely as an unfortunate necessity."

Aristotle also put forward three elements of constitutional government. First, the government is implemented for the public interest. Second, 
governance is carried out according to laws based on general provisions, not laws made arbitrarily which override conventions and the constitution. Third, a constitutional government that is implemented based on the will of the people. Aristotle's thought is recognized as the ideals of the rule of law known to this day. These three elements are almost found and practiced by all countries that identify themselves as a rule of law.

Burkens explains the simple meaning of rechsstaat as quoted by A. Hamid S. Attamimi (1992), namely a state that places law as the basis of state power and the exercise of this power in all its forms is carried out under the rule of law. In rechsstaat, according to him, the bond between the state and the law does not take place in a loose or accidental relationship but is an essential bond.

\subsection{Equality Before The Law Theory}

The Republic of Indonesia is a country based on law. The 1945 Constitution stipulates that the Republic of Indonesia is a constitutional state (rechstsaat) as evidenced by the provisions in the preamble, body, and explanation of the 1945 Constitution (Melissa Walukow, 2013). In the Amendment to the 1945 Constitution, the theory of equality before the law is included in Article 27 paragraph (1) which states that: All citizens have the same position in law and government and are obliged to uphold the law and government without exception. This is a recognition and guarantee of the equal rights of all citizens in law and government.

The theory and concept of equality before the law as adopted by Article 27 paragraph (1) of the Amendment to the 1945 Constitution is the basis of protection for citizens to be treated equally before law and government. This means that all people are treated equally before the law. Equality before the law or equality before the law is one of the most important principles in modern law. This principle is one of the pillars of the Rule of Law doctrine which also spreads to developing countries such as Indonesia. If it can be stated that the principle of equality before the law is one of the manifestations of the rule of law (rechtstaat) so that there must be equal treatment for everyone before the law (gelijkheid van ieder voor de wet) (Lilik Mulyadi, 2007). Thus, the inherent element implies equal justice under the law and obtaining equal justice before the law.

The principle of rule of law teaches that communication and social interaction consisting of various elements of the community interact and transact to achieve common goals and ideals. Whereas the order of life and communication between individuals in a community refers to the agreed rules of the game and is used as a reference and reference for the parties in conducting relationships and legal actions. Based on this concept, there is no arbitrariness carried out by law enforcers or justice seekers, thus giving birth to a civil society in which individuals as people or citizens have the same and equal position before the law.

The principle of equality before the law is a guarantee for achieving justice (law), without the absence of parties who can be separated when involved in the law enforcement process. Legal protection guarantees are implied in the principle of equality before the law, namely guarantees that not only get the same treatment but will also bring logical consequences that the law will not give privileges to other legal subjects. Because if this happens it will violate the principle of equality before the law and will encourage discrimination before the law (Suwandoko, S., \& Rihardi, S. A. 2020).

The concept of equality before the law has been introduced into the constitution, the highest recognition in the system of statutory regulations in the country, this principle means that equality before the law is for the same case (criminal act). In reality, there is usually no equal treatment and that causes the rights of individuals to obtain justice (access to justice) to be neglected. Different treatment in criminal acts of corruption, for example, causes the neglect of individual freedom. This means legal certainty is neglected (Mustari, 2018).

The principle of equality before the law must always be upheld for the sake of the rule of law and the judicial system. Because a constitutional state must guarantee human rights for its citizens. In this context, no one should immediately impose a sentence to enforce the law by violating this principle. Do not let anything happen to give punishment (judgment) outside the existing rules or system.

\subsection{Principles of Protection and Fulfillment of Human Rights for Persons with Disabilities in Indonesia}

Law Number 39 of 1999 concerning human rights provides legal certainty for the protection of human rights for everyone. Persons with disabilities are human beings, so the human rights of persons with disabilities 
must be protected and their needs fulfilled. Based on the Law of the Republic of Indonesia Number 39 of 1999 concerning Human Rights in CHAPTER I, General Provisions Article 1, Human Rights are a set of rights inherent in the essence of human existence as a creature of God Almighty and it is His gift that must be respected., is upheld and protected by the state, law, government, and everyone for the honor and protection of human dignity. Respect and dignity for human rights is a noble thing. The existence of mutual respect, tolerance among fellow creatures of God Almighty, can always provide a sense of peace for anyone in this world (Gayatri, I. A. M., \& Juliantari, N. K. 2019).

Since its emergence until today, human rights have undergone development and changes known as the human rights generation, the first generation includes civil and political rights, the second generation includes social, economic, and cultural rights, finally, the third generation contains several rights. -Collective rights, such as the right to development/progress (development), the right to peace, the right to a clean environment, the right to natural resources, and the right to cultural heritage (Satjipto Raharjo, 2009).

The government, a society based on law are obliged to protect and uphold human rights so that the principles, benefits, and equality inherent in all human beings are carried out properly so that there is no more discrimination. What he wants to explain is that people and nations in the world are diverse, diverse in their physical habitats, cultural traditions, values, cosmology, and their views about humans and the world (Halimatussadiah, et al., 2017).

The statement contained in the Preamble to the Universal Declaration of Human Rights was received and announced by the UN General Assembly on 10 December 1948 through resolution No. 217 (III). One of the sentences state "considering that recognition of the natural dignity and the equal and inalienable rights of all members of the human family is the basis of freedom, justice, and world peace. Considering that human rights need to be protected by legal regulations so that people are not forced to choose the path of rebellion as a last resort to oppose tyranny and colonialism.

These sentences are guidelines for regulations regarding human rights which are also adapted to the legal needs of the community and the development of national law based on Pancasila and the 1945 Constitution which are embodied in the Law of the
Republic of Indonesia Number 39 of 1999 concerning Human Rights.

The conception of human rights, which initially emphasized vertical relations, was mainly influenced by the history of human rights violations that were primarily committed by the state, both against civilpolitical rights as well as economic, social, and cultural rights. As a consequence, apart from being the government's duty, the main obligation to protect and promote human rights lies with the government. We can see this from the formulations in the Universal Declaration of Human Rights, the International Covenant on Civil and Political Rights, and the International Covenant on Economic, Social, and Cultural Rights, which are state recognition of human rights as the substance of the three instruments.

As a consequence, it is the state that is burdened with the obligation to protect and promote human rights. The state's obligation is emphasized in the preamble "Considering" both in the International Covenant on Civil and Political Rights and the International Covenant on Economic, Social, and Cultural Rights. In national law, Article 28I paragraph (4) of the 1945 Constitution states that the protection, advancement, upholding, and fulfillment of human rights are the responsibility of the state, especially the Government.

\section{RESEARCH METHODS}

Research is the main means of developing science, including technology. The research aims to reveal the truth systematically, methodologically, and consistently. Thus, the research was conducted through analysis and construction of existing data (Soekanto \& Sri Mamudji, 2006). Research is an effort to explore an object that is unclear, obscure, or even without explanation for it. A logical and systematic study of the principles that guide scientific research (methodology) is intended as a basic principle and not as a method (method or design for conducting research) (Sumardjono, 1989).

Searching for new things through research to find, develop, and test the truth (Wignjosoebroto, 2013) of knowledge (Abdurrahman, 2009). The search through this research must of course meet scientific principles to find answers to a matter, problem, situation, fact, or phenomenon faced by humans. This truth search requires a scientific method to find the truth based on logical considerations (Sumardjono, 2014). 
The author conducted legal research regarding the fulfillment of labor rights for persons with disabilities in Indonesia and is prospective. This research can qualify as normative legal research, because it examines the rules or norms contained in the law regarding Indonesian government policies regarding the fulfillment of the rights of persons with disabilities in Indonesia, including related laws and regulations, and which are of relevance. with that. This research can also qualify as prospective legal research because this study it is expected to provide conceptual input on Indonesian government policies in fulfilling the rights of persons with disabilities (Nurhayati, S. 2020).

The data in this normative legal research is obtained by searching the literature or documents. Sources of literature or documents come from primary legal materials, secondary legal materials, and tertiary legal materials. Data collection in the study was carried out using documentation methods, and data collection tools were carried out through document study. Document studies are carried out by reviewing and tracing primary legal materials, secondary legal materials, and tertiary legal materials.

The tools and methods used to collect this data are by taking notes, or through photocopies of documents that are relevant to the object of research. This document can be in the form of publications, laws, and regulations, as well as various information contained in local government policies regarding persons with disabilities in Indonesia.

Data analysis is an activity of analyzing data that researchers have collected, whether obtained through library research or field research. The analysis is carried out by classifying, systematizing which is then evaluated to support the resolution of the problem being researched, with the hope that the right conclusions will be obtained.

\section{DISCUSSION}

\subsection{Fulfillment of Labor Rights for Persons with Disabilities in Indonesia}

The Post-Amendment 1945 Constitution includes Chapter XA which discusses human rights. The provisions in that Chapter serve as a form of protection for the constitutional rights of citizens in general, including citizens with disabilities. The goal is that persons with disabilities who are part of Indonesian society have the same position, rights, and obligations as other citizens and for its implementation, it is the obligation of the Government and all elements of society.

In Chapter XA of the 1945 Constitution, there are 10 articles, namely Article $28 \mathrm{~A}$ to Article $28 \mathrm{~J}$, which cover 26 provisions scattered in the paragraphs in the existing Articles. The entire provision can be divided into two types, namely protection of human rights specifically for citizens and protection of human rights for everyone, which means not only Indonesian citizens. In the two types of groups there are no other classifications, which means, whether, in the type of protection for citizens or everyone, groups of persons with disabilities are included in both (Susiana, W).

Fulfillment and protection of the rights of persons with disabilities are all actions and/or activities to guarantee and protect the constitutional rights of persons with disabilities following human dignity and to avoid acts of violence and discrimination. The objectives of protecting and fulfilling the rights of persons with disabilities include: increasing the level of welfare, quality and survival, and independence of persons with disabilities; (a) increase the social and economic resilience of persons with disabilities; (b) increase the capacity, concern, and responsibility of the Provincial Government, the business community and the community in institutional and sustainable protection and fulfillment of the rights of persons with disabilities; and (c) improve the quality of life and livelihoods of persons with disabilities (Wijayanti, S. W\&Manurung, L).

From the explanation above, the 1945 Constitution has explicitly protected the constitutional rights of persons with disabilities in the context of "everyone" and as part of "citizens". Also, people with disabilities are also allowed to get affirmative action or the right to convenience and special treatment in the context of fulfilling rights constitutionality. Both concepts must be understood and absorbed in the formation of laws and regulations as well as policies as an implementation of the provisions of the 1945 Constitution.

The Republic of Indonesia which is based on Pancasila (Kaelan) and the 1945 Constitution of the Republic of Indonesia respects and upholds human dignity. Human rights as basic rights that are inherently universal, need to be protected, respected and defended, so that protection and human rights for vulnerable groups, especially Persons with Disabilities.

Respect, protection, and fulfillment of the rights of persons with disabilities are the obligations of the state. 
This is also emphasized in Law Number 39 of 1999 concerning Human Rights so that society has the responsibility to respect the rights of Persons with Disabilities. During this time, Persons with Disabilities have experienced a lot of discrimination which results in the unfulfilled implementation of the rights of persons with disabilities. So far, the regulation regarding persons with disabilities is regulated in Law Number 4 of 1997 concerning Persons with Disabilities, but this regulation does not have a human rights perspective. The content material in Law No.4 of 1997 concerning persons with disabilities is more charity based and the fulfillment of the rights of persons with disabilities is still considered a social problem whose fulfillment policies are only social security, social rehabilitation, social assistance, and improvement of social welfare. . Persons with disabilities should have equal opportunities in efforts to develop themselves through independence as dignified human beings (Meithiana, I., \& Riyadi, S. 2019).

The passing of Law Number 19 the Year 2011 concerning the Ratification of the Convention on the Rights of Persons with Disabilities on November 10, 2011, demonstrates the commitment and seriousness of the Indonesian Government to respect, protect and fulfill the rights of persons with disabilities which in turn are expected to improve the welfare of persons with disabilities. Thus, persons with disabilities have the right to be free from torture or other cruel, inhuman, degrading treatment, free from exploitation, violence, and abuse, and the right to receive respect for their mental and physical integrity based on equality with others, including in it the right to get protection and social services in the context of independence, as well as in an emergency. Therefore, the Government is obliged to realize the rights contained in the convention, through adjustments to laws and regulations, including ensuring the fulfillment of the rights of persons with disabilities in all aspects of life such as education, health, work, politics and governance, culture and tourism, and the use of technology. information, and communication (Zahran, W. S. 2018).

Labor protection aims to ensure the basic rights of workers, guarantee equality and any discrimination to achieve the welfare of workers and their families while still taking into account the development of the business world and the interests of employers. Persons with disabilities often face discrimination, as do people with disabilities who find it difficult to find work. The laws and regulations related to labor protection are Law
Number 13 of 2003 concerning Manpower and its implementing regulations in the field of manpower. In theory, work protection is divided into the following three types: 1 . Social protection is protection related to community efforts, the goal of which is that workers/laborers can enjoy and develop their lives like ordinary people, especially as members of the community and family members. Social protection is also called occupational health. " 2. Technical protection, which is a type of protection related to business. Efforts to protect workers or laborers from accidents caused by work tools or materials. This kind of protection is commonly called work safety. What is meant by technical protection includes work safety, namely protection of workers or laborers from possible dangers caused by the use of work tools or materials. 3. Economic protection is a type of protection that relates to providing sufficient income to workers or workers to meet their daily needs and their families, including when workers or workers are unable to work for other reasons against their will. This protection is commonly called social security ".

According to Law Number 13 of 2003 concerning Manpower, a work contract or work agreement is an agreement between a worker/worker and an employer or employer that contains the working conditions, rights, and obligations of both parties. Article 89 of the "Manpower Law" stipulates that the government stipulates the minimum wage according to the needs of a decent life and takes into account productivity and economic growth. The minimum wage can include the minimum wage by province or region/city and the minimum wage by province or region/city. Persons with disabilities are subject to the law, and in this case, they have the right to carry out legal actions. Therefore, there is absolutely no reason for laws or policies to prohibit persons with disabilities from participating in the life of society, nation, and state. Persons with disabilities are often considered legally incompetent, especially when taking legal action.

This prevents persons with disabilities from getting decent work and can lose their rights and possibly unfair treatment in social life. Workers with disabilities themselves get legal protection in Article 86 of the Manpower Law, which stipulates that every worker has the right to; 1 . Occupational safety and health; 2 . Morals and morals; 3 . Treatment following human dignity and religious values.

In the Law on Persons with Disabilities, guarantees for the participation of persons with disabilities in the 
world of work are clearly stated. Article 5 paragraph (1) letter $F$ states that Persons with Disabilities have the right to work, entrepreneurship, and cooperatives. This provision is clarified in article 11 , especially in letters $A$ and $B$, which states that the right to work for Persons with Disabilities includes the right to obtain work organized by the Government, Local Government, or the private sector without discrimination and receive the same wages as non-disabled workers. the same type of work and responsibilities. More specifically, article 53 paragraph (1) and paragraph (2) states that the Government, Regional Government, State-Owned Enterprises and Region-Owned Enterprises are required to employ at least $2 \%$ (two percent) of Persons with Disabilities of the number of employees or workers. while private companies are required to employ at least $1 \%$ (one percent) of Persons with Disabilities of the total number of employees or workers.

Reward and punishment are one of the approaches used by the government to increase the participation of persons with disabilities in the world of work. Based on article 54 paragraph (1) of the Law on Persons with Disabilities, it is explained that the Government and Regional Governments are obliged to provide incentives to private companies that employ Persons with Disabilities, wherein the explanation of the article explains the incentives given to private companies that carry out these provisions, including in the form of easy licensing. , awards, and assistance in providing work facilities that are easily accessible. Likewise, on the contrary, based on article 143 of the same law it is stated that Everyone is prohibited from obstructing and/or prohibiting Persons with Disabilities from obtaining the right to work, entrepreneurship, and cooperatives as referred to in Article 11. This provision is strengthened by the imposition of criminal sanctions as referred to in Article 11. stated in article 145, where the article confirms that Everyone who obstructs and/or prohibits Persons with Disabilities from obtaining the rights referred to in Article 143 shall be punished with imprisonment of up to 2 (two) years and a maximum fine of Rp.200,000,000.00 (two hundred million rupiahs).

The existence of the National Disability Commission (KND) is at the core of the application of all laws and regulations relating to persons with disabilities. The provisions regarding the formation of the KND have been explicitly stated in article 131 of the Law on Persons with Disabilities. In this article, it is explained that in the context of implementing the Respect,
Protection, and Fulfillment of the rights of Persons with Disabilities, the KND was formed as an independent non-structural institution. The task of the KND itself is to carry out monitoring, evaluation, and advocacy for the implementation of respect, protection, and fulfillment of the rights of Persons with Disabilities as stated in article 132 paragraph (1).

\section{CONCLUSION}

Indonesia is a country that highly upholds human rights. Protection and fulfillment of human rights are given to every Indonesian citizen without exception including Indonesian citizens with disabilities. However, empirically the Government of Indonesia is faced with challenges in fulfilling the rights to work for persons with disabilities themselves. Persons with disabilities also face various challenges in obtaining their right to work, such as a negative stigma from society; terms and conditions and employment that do not provide opportunities for them to work; their educational backgrounds that do not meet the requirements of workers; and the shame they experience at the expense of their physical condition. The passing of Law Number 19 the Year 2011 concerning the Ratification of the Convention on the Rights of Persons with Disabilities on November 10, 2011, shows the commitment and seriousness of the Indonesian Government to be committed to respecting, protecting, and fulfilling the rights of persons with disabilities, especially in the field of work, which in turn is expected to improve the welfare of persons with disabilities. Thus, persons with disabilities have the right to be free from torture or cruel, inhuman, degrading treatment, free from exploitation, violence, and abuse, and the right to receive respect for their mental and physical integrity based on equality with others, including in it the right to get social protection and services in the context of independence, as well as in an emergency.

\section{SUGGESTIONS}

With the existence of Law Number 19 the Year 2011 concerning Ratification of the Convention on the Rights of Persons with Disabilities, the Government is obliged to realize the rights contained in the convention, through adjustments to laws and regulations, including ensuring the fulfillment of the rights of persons with disabilities in all aspects of life such as education, health, employment, politics and government, culture and tourism, as well as the use of technology, information, and communication. 


\section{ACKNOWLEDGEMENTS}

Thanks to Batanghari University and the Ganesha University of Education for providing the opportunity for us to carry out research related to the fulfillment of labor rights in Indonesia.

\section{REFERENCES}

A. Hamid S. Attamimi, 1992, Teori Perundang-undangan, Pidato pengukuhan Jabatan Guru Besar Tetap Fakultas Hukum UI, 25 April 1992, p. 8

Asikin, Zainal, et al. 2006. Dasar-dasar Hukum Perburuhan. Jakarta: Rajawali Pers

Awaliyah Siti et al. (2020), Enforcement of Illegal Fishing Laws that was Done by Foreign Ships in the Indonesian Sea Region, Viewed from International Sea Law, International Journal of Criminology and Sociology, Volume 9. https://doi.org/10.6000/1929-4409.2020.09.137

Departemen Hukum Dan HAM RI, 2008, Bahan Bacaan Training of Trainer HAM, Direktorat Jenderal HAM, Depok, p. 2

Gayatri, I. A. M., \& Juliantari, N. K. 2019. The Fulfillment of Religious and Customary Rights For Persons with Disabilities in Bali. Vidyottama Sanatana: International Journal of Hindu Science and Religious Studies, 3(1), 79-91. https://doi.org/10.25078/ijhsrs.v3i1.803

George Sabine, 1995, A History of Political Theory,George G.Harrap \& CO.Ltd., London, p. 92. Lihat juga Dahlan Thaib, 2000, Kedaulatan Rakyat, Negara Hukum dan Hakhak Asai Manusia, p. 22

Halimatussadiah, A., Nuryakin, C., Muchtar, P. A., Bella, A., \& Rizal, H. 2017. Mapping Persons with Disabilities (PWDs) in Indonesia Labor Market. Economics and Finance in Indonesia, 63(2), 126-149. https://doi.org/10.7454/efi.v63i2.572

Julita Melissa Walukow, "Perwujudan Prinsip Equality Before The Law Bagi Narapidana Di Dalam Lembaga Pemasyarakatan Di Indonesia", dalam Lex et Societatis, Vol.I/No.1/JanMrt/2013, p. 1

Kaelan, Pancasila Sebagai Dasar Penjabaran Hak-Hak Asasi Manusia, Jurnal Filsafat No. 2 Tahun 1992, Fakultas Filsafat UGM, Yogyakarta, p. 34

Khairani, Analisis Permasalahan Outsourching (Alih Daya) dari Perspektif Hukum dan Penerapannya, Kanun Jurnal IImu Hukum No. 56 Th XIV, 2012, p. 55.

Lalu Husni, 2003, Pengantar Hukum Ketenagakerjaan Indonesia (edisi revisi), Jakarta: PT. Raja Grafindo, p. 24

Lilik Mulyadi, 2007, Hukum Acara Pidana, Citra Aditya Bakti, Jakarta, p. 20

Mangku Dewa Gede Sudika et al. (2020), Compensation for Oil Pollution Due to Tanker Accidents in the Indonesian Legal System in a Justice Value Perspective, International Journal of Criminology and Sociology, Volume 9. https://doi.org/10.6000/1929-4409.2020.09.63

Mangku, D. G. S. 2020. Perlindungan Hukum Terhadap Anak-Anak Disabilitas Terkait Hak Pendidikan di Kabupaten Buleleng. Jurnal Magister Hukum Udayana (Udayana Master Law Journal), 9(2), p. 353-365. https://doi.org/10.24843/JMHU.2020.v09.i02.p11

Mangku, D. G. S., \& Yuliartini, N. P. R. 2019, Indonesia's Role In Enabling Asean 2025 Masterplants To Promote And Protect Disability Rights In ASEAN. South East Asia Journal of Contemporary Business, Economics and Law, Vol. 18, Issue 4 (April).

Maria SW. Sumardjono, 1989, Pedoman Pembuatan Usulan Penelitian, tanpa penerbit, Yogyakarta, p. 6.
Maria SW. Sumardjono, 2014, Metodologi Penelitian IImu Hukum, Bahan Kuliah, Universitas Gadjah Mada, Yogyakarta, p. 5

Meithiana, I., \& Riyadi, S. 2019. Implementation of Empowerment Program for Person With Disability in Indonesia. Journal of Advanced Research in Dynamical and Control Systems, 11(7), 298-303

Muslan Abdurrahman, 2009, Sosiologi dan Metode Penelitian Hukum, UMM Press,Malang, 2009, p. 91.

Mustari, M. (2018, October). Government Duty In Fulfillment Of Rights To Work For People With Disability In Makassar South Sulawesi. In 1st International Conference on Social Sciences (ICSS 2018). Atlantis Press. https://doi.org/10.2991/icss-18.2018.207

Ni'matul Huda, 2005, Negara Hukum, Demokrasi dan Judicial Riview, UII Press, Yogyakarta, p.1

Nurhayati, S. 2020. Social Inclusion For Persons With Disabilities Through Access To Employment In Indonesia. Prophetic Law Review, 2(1), 1-21. https://doi.org/10.20885/PLR.vol2.iss1.art1

Philipus M. Hadjon, 1996, Kedaulatan Rakyat,Negara Hukum dan Hak-hak Asasi Manusia, Kumpulan Tulisan dalam rangka 70 tahun Sri Soemantri Martosoewignjo,Media Pratama,Jakarta, p. 72

Rizqa Maulinda, Dahlan, M. Nur Rasyid, Perlindungan Hukum bagi Pekerja Kontrak Waktu Tertentu dalam Perjanjian Kerja pada PT. Indotruck Utama, Kanun Jurnal IImu Hukum Vol. 18 No. 3, 2016, p. 337- 351 .

Purwendah Elly Kristianti and Mangku Dewa Gede Sudika (2021), Implementation of Compensation for Oil Pollution by Tanker Ships in the Indonesian Legal System, International Journal of Criminology and Sociology, Volume 9. https://doi.org/10.6000/1929-4409.2021.10.15

Satjipto Raharjo, 2009, Hak Asasi Manusia Dalam Masyarakatnya dalam Muladi (ed), 2009, Hak Asasi Manusia Hakekat, Konsep dan Implikasinya dalam Perspektif Hukum dan Masyarakat, PT Reflika Aditama, Bandung, p. 219

Suastika I Nengah et al. (2020), The Multi-Etnik Community Integration Model in Bali: Pholosphical Base and Proto Multiculturalism in Balinese Society, International Journal of Criminology and Sociology, Volume 9. https://doi.org/10.6000/1929-4409.2020.09.142

Soerjono Soekanto, dan Sri Mamudji, 2006, Penelitian Hukum Normatif; Suatu Tinjauan Singkat, PT. Rajagrafindo Persada, Jakarta, p. 1.

Soetandyo Wignjosoebroto, 2013, Hukum, Konsep, dan Metode, Setara Press, Malanng, p. 11

Susiana, W. Indonesian Government Policies in Protecting the Rights of People with Disabilities in Getting a Job at Indonesian State-Owned Enterprises.

Sutedi Ardrian, 2011, Hukum Perburuhan, Sinar Grafika, Jakarta 2011, p. 142.

Suwandoko, S., \& Rihardi, S. A. 2020. Legal Reform for the Fulfilment of Disabilities Human Rights. Unnes Law Journal, 6(2), 217-224.

https://doi.org/10.15294/ulj.v6i2.38973

Undang Undang Nomor 4 Tahun 1997 Tentang Penyandang Cacat (Lembaran Negara Tahun 1997 Nomor 9, Tambahan Lembaran Negara Nomor 3670)

Undang Undang Nomor 8 Tahun 2016 Tentang Penyandang Disabilitas (Lembaran Negara. Nomor 69. Tambahan Lembaran Negara. Nomor 5870).

Undang-Undang Nomor 19 Tahun 2011 tentang Pengesahan Convention On The Right Of Persons With Disabilities (Lembaran Negara Republik Indonesia Tahun 2011 Nomor 107, Tambahan Lembaran Negara Republik Indonesia Nomor 5251).

Undang-Undang Nomor 39 Tahun 1999 tentang Hak Asasi Manusia 
Wijayanti, S. W., Manurung, L., \& Santoso, A. Disability in the Labor Market: Learning from Indonesia in Implementing Affirmative Policies for Persons with Disabilities.

Yuliartini Ni Putu and Mangku Dewa Gede Sudika (2020), Legal Protection for Women Victims of Trafficking in Indonesia in an International Human Rights Perspective, International Journal of Criminology and Sociology, Volume 9. https://doi.org/10.6000/1929-4409.2020.09.160

Yuliartini, N. P. R., \& Mangku, D. G. S. 2020. Peran Dinas Tenaga Kerja Transmigrasi Kabupaten Buleleng Dalam Penempatan
Dan Pemberian Perlindungan Hukum Tenaga Kerja Indonesia Di Luar Negeri. Jurnal Pendidikan Kewarganegaraan Undiksha, 8(2), 22-40. http://dx.doi.org/10.23887/jpku.v8i2

Zahran, W. S. 2018. The Implementation Of Public Policy On Accessibility For People With Disabilities In Employment Opportunity: A Case Study Of Indonesia. European Journal of Research and Reflection in Management Sciences Vol, 6(1).

DOI: https://doi.org/10.6000/1929-4409.2021.10.33

(C) 2021 Nazifah et al.; Licensee Lifescience Global.

This is an open access article licensed under the terms of the Creative Commons Attribution Non-Commercial License (http://creativecommons.org/licenses/by-nc/3.0/) which permits unrestricted, non-commercial use, distribution and reproduction in any medium, provided the work is properly cited. 